\title{
The Impact of Communication Satisfaction and Demographic Variables on Employee Engagement
}

\author{
Fatma Jaupi, Shyqyri Llaci \\ Faculty of Economy, Tirana University, Tirana, Albania \\ Email: fatmajaupi@feut.edu.al, shyqyrillaci@feut.edu.al \\ Received 3 February 2015; accepted 30 March 2015; published 1 April 2015 \\ Copyright (C) 2015 by authors and Scientific Research Publishing Inc. \\ This work is licensed under the Creative Commons Attribution International License (CC BY). \\ http://creativecommons.org/licenses/by/4.0/ \\ (c) (i) Open Access
}

\begin{abstract}
The focus of this paper is the relationship of employee engagement with organizational communication. Moreover, the research investigates the relationship of the demographic determinants with employee engagement in Albanian bank sector. The research shows that the communication satisfaction dimensions strongly impact employee engagement. The relationship between demographic variables and employee engagement is presented in the study as well. This research does have practical implications for bank sector, mainly for top management and human resources department as how to increase the engagement of the employees.
\end{abstract}

\section{Keywords}

Employee Engagement, Communication Satisfaction, Demographic Determinants

\section{Introduction}

There is a general belief that there is a connection between employee engagement and business results; a metadata analysis conducted by Harter et al. (2002) [1] confirms this connection. The conclusion was that "employee satisfaction and engagement are related to meaningful business outcomes at a magnitude that is important to many organisations".

The Gallup Organisation (2006) [2] found that only 29\% of the US working population were engaged (loyal and productive), 55\% were not engaged (just putting in time), and 15\% were actively disengaged (unhappy and spreading their discontent). Ott (2007) [3] cited Gallup research, which found that higher workplace engagement predicted higher earnings per share (EPS) among publicly traded businesses. According to ISR (an employee research and consulting company) results on a global survey, carried out with more than 664,000 employees, "a 
well-substantiated relationship exists between employee engagement - the extent to which employees are committed, believe in the values of the company, feel pride in working for their employer and are motivated to go the extra mile-and business results", the latter being defined as operating income, and EPS over a 12 month period (Towers Perrin-ISR, 2006) [4]. Research indicates that companies that focus on employee engagement present higher levels of customer satisfaction as well, leading to improved customer retention and increased sales (Frank et al., 2004) [5].

The paper research will focus specifically on employee engagement in Albanian bank sector. Apart of the innovation and technology advancement, which are important as a competitive advantage, the next step the companies are trying to go further is to win a competitive advantage on human resources. While it's easy to copy, absorb and transfer the technology and innovation, imperative remains how to engage the company's human resources. The research investigates into detail how communication practices impact the employee engagement and to what extent the demographic characteristics are related with employee engagement.

\section{Theory and Hypothesis}

\subsection{Employee Engagement}

The definition of employee engagement is relatively unclear (Dalal et al., 2008) [6]. While the construct has established itself firmly in the practitioner community, it remains a concept with a "sparse and diverse theoretical and empirically demonstrated nomological net” (Marcey \& Schneider, 2008) [7], or one in which the exact component of engagement need to be rigorously and empirically established.

The term embracement to describe the investment of "self" and "energy into one's role" (Goffman, 1959) [8] was used by the researcher Goffman. "Role embracement" involved admitted or expressed attachments to the role and an active engagement or spontaneous involvement in role activity; that is a visible attention and effort (Goffman, 1961) [9]. On the basis of Goffman's definition of role embracement, Kahn (1960) [10] established a theoretical framework to understand the situations when employees invest varying degrees of themselves in work role performance. Kahn explored conditions at work where people were personally engaged or were disengaged and withdrew and defended their personal selves. From this, Kahn developed a definition of engagement to include "the simultaneous employment and expression of a person's "preferred self" in task behaviours that promote connection to work and to others, personal presence (physical, cognitive and emotional) and active full performances. Maslach et al. (1996) [11] defined the engagement construct as the opposite of burnout (i.e. someone not experiencing job burnout must be engaged in their work). Harter \& Schmidt (2006) [12] define employee engagent as the "individual's involvement and satisfaction with as well as enthusiasm for work". Schaufeli et al. (2002) [13] define engagement as a persistent, positive affective-motivational state of fulfillment in employees that is characterized by vigor, dedication and absorption. Though different autors use dissimilar terms to define and explain employee engagement, there are consistently occurring themes presenting employee engagement: as a desirable condition; has positive impacts on organisational efficacy and connotes involvement, commitment, passion, enthusiasm, focused effort and energy.

\subsection{Communication Satisfaction}

The communication satisfaction construct presented by Downs and Hazen (1977) [14] has become a successful research stream in organizational communication. Communication Satisfaction consists of the following constructs: communication climate, communication with supervisors and with subordinates, organisational integration, media quality, horizontal communication, organizational perspective and personal feedback (Downs \& Hazen, 1977) [14].

Frank \& Brownell (1989) [15] define employee communication as communication transactions between individuals and/or groups at various levels and in different areas of specialization that are intended to design and redesign organizations, to implement design and contribute from day-to-day activities. Employees become concerned about the future of the organization and will start thinking about leaving the organization when they perceive absence of consistent and honest communication (Durkin, 2007) [16]. From this perspective, Durkin (2007) [16] suggested that organization should share clearly with all the employees it's vision and values and ideally, this should go beyond just making profits. Employees would feel more obliged to make difference and to ensure that they are adding value to others. 
The lack or poor communication is perhaps the most common problem among companies nowadays. Most employees, regardless of their position in the organization, will cite communication as an area in their workplace that needs improvement (Prime Resources, Inc, 2009) [17]. The fundamental purpose of internal communication is to improve performance by changing the behaviour of all employees, including managers (Steyen \& Groenewald, 1996) [18].

\subsection{Research Objectives and Hypothesis}

The research has the objective to study the impact of employee organizational communication on employee engagement. In addition, the research objective is to investigate until what extends is the relationship of gender, age group, highest level of education, and position within organization, years of experience, and years of experience in the organization into the engagement of employees. On the basis of two main objectives, the following hypothesis will be investigated:

- H1: Gender has positive relationship with employee engagement.

- H2: Age group has positive relationship with employee engagement.

- H3: Highest level of education has positive relationship with employee engagement.

- H4: Country of study has positive relationship with employee engagement.

- H5: Position within organization has positive relationship with employee engagement.

- H6: Years of experience has positive relationship with employee engagement.

- H7: Years of experience in the organization has positive relationship with employee engagement.

- H8: There is significant relationship between employee engagement and employee communication and the employee communication is a predictor for the employee engagement level.

\section{Method}

\subsection{Survey Instruments and Model Measures}

The primary data used in this research are collected through 405 questionnaires distributed to the employees in the bank sector.

The questionnaire had a dedicated section on general and demographic information questions. The second part of the questionnaire was composed of the questions measuring the organizational communication satisfaction. Since review of the literature clearly suggests that organizational communication plays a profound role in shaping employee attitudes, the communication is considered as an antecedent of employee engagement. The organizational communication satisfaction was measured through the Communication Satisfaction Questionnaire (CSQ) developed by Downs Hazen (1977) [14].

The section dedicated employee engagement (characterized by vigor, dedication and absorption) is composed of questions to measure employee engagement through Utrecht Work Engagement Scale. The Likert scale, starting from 1 (I am not at all satisfied) to 5 (I am fully satisfied) is applied.

\subsection{Participants and Data Collection}

The questionnaire was distributed to 405 employees, part of the bank sector services in Albania, central and second levels banks. The non-response rate (Lohr, 2010) [19] was 1\%. The sample consisted of employees from all age groups and position within organization.

The questionnaire was previously piloted as a first phase among employees. The sample selection for bank selection distributed in the country is drawn randomly aiming to produce representative results at national level. SPSS 15.0 is used for the data analysis.

\section{Data Analysis}

\subsection{Description of Sample}

Table 1 presents the values for respondents by gender, age group, level of education, years of experience, position within organisation and years of experience in organisation.

The values of the respondents, coming from Table 1 , shows that $40.6 \%$ of employees are part of their organizations from 5 - 10 years, and 54\% of employees are part of their organizations for below 5 years. For the group 
Table 1. Distribution of demographics variables.

\begin{tabular}{|c|c|c|c|c|c|}
\hline \multicolumn{3}{|c|}{ Gender } & \multicolumn{3}{|l|}{ Age-group } \\
\hline & Frequency & Percent & & Frequency & Percent \\
\hline Male & 130 & 32.2 & 20 - 29 years & 149 & 36.9 \\
\hline Female & 274 & 67.8 & 30 - 39 years & 204 & 50.5 \\
\hline Total & 404 & 100.0 & $40-49$ years & 34 & 8.4 \\
\hline \multicolumn{3}{|c|}{ Highest completed level of education } & 50 - 59 years & 17 & 4.2 \\
\hline & Frequency & Percent & Total & 404 & 100.0 \\
\hline Upper secondary & 11 & 2.7 & \multicolumn{3}{|c|}{ Years of experience } \\
\hline Bachelor & 120 & 29.7 & & Frequency & Percent \\
\hline Master professional/scientific & 264 & 65.3 & Below 5 years & 133 & 32.9 \\
\hline Doctorate/PhD & 9 & 2.2 & 5 - 10 years & 161 & 39.9 \\
\hline Total & 404 & 100.0 & $10-15$ years & 52 & 12.9 \\
\hline \multicolumn{3}{|c|}{ Country of study } & 15 - 20 years & 34 & 8.4 \\
\hline & Frequency & Percent & 20 - 25 years & 6 & 1.5 \\
\hline State university in Albania & 290 & 71.8 & 25 years and above & 18 & 4.5 \\
\hline Private university in Albania & 53 & 13.1 & \multirow{2}{*}{ Total } & \multirow{2}{*}{404} & \multirow{2}{*}{100.0} \\
\hline Total & 404 & 100.0 & & & \\
\hline \multicolumn{3}{|c|}{ Years of experience in the organization } & \multicolumn{3}{|c|}{ Position within organization } \\
\hline & Frequency & Percent & & Frequency & Percent \\
\hline Below 5 years & 218 & 54.0 & Specialist & 275 & 68.1 \\
\hline 5 - 10 years & 164 & 40.6 & Low level manager & 85 & 21.0 \\
\hline 10 - 15 years & 15 & 3.7 & Middle level manager and senior leaders & 44 & 10.9 \\
\hline 15 - 20 years & 2 & 0.5 & Total & 404 & 100.0 \\
\hline 20 - 25 years & 4 & 1.0 & & & \\
\hline 25 years and above & 1 & 0.2 & & & \\
\hline Total & 404 & 100.0 & & & \\
\hline
\end{tabular}

"years in the organization 10 - 15 and above", the percentage decreases rapidly. The data shows that the employee turnover becomes higher after ten years in one organization. After having 10 years experience in the company, the employees tend to change the organization, the turnover is quite distinguished. Another characteristics of the employees in bank sector is the young age, $87.4 \%$ are of group age 20 - 39 years. And the last characteristics presented are that $65.3 \%$ of employees hold a master professional/scientific. The composition is quite young, very well educated and after the tenth year of work they leave the company. The challenge is to engage the employees to turn as a competitive advantage while the HR of the company has invested in their trainings, on the job qualifications, etc.

Figure 1 present the educational background of the respondents and the position hold in the company. The level of education presented provide strong basis for reliable response on the communication and employee engagement in the organisations they are part.

\subsection{Correlation Analysis}

To test the hypothesis on the significance of demographic section questions (gender, education, years in organi- 
zation, experience, position within organization, age group) a correlation is established between all demographic variables and employee engagement. As already known, correlation is a bivariate measure of association (strength) of the relationship between two variables. It aims at ascertaining whether or not two variables) are varying together. It varies from 0 (no-relationship) to 1 (perfect linear relationship) or -1 (perfect negative linear relationship).

Table 2 of Correlation matrix shows the following relationship of employee engagement with demographic

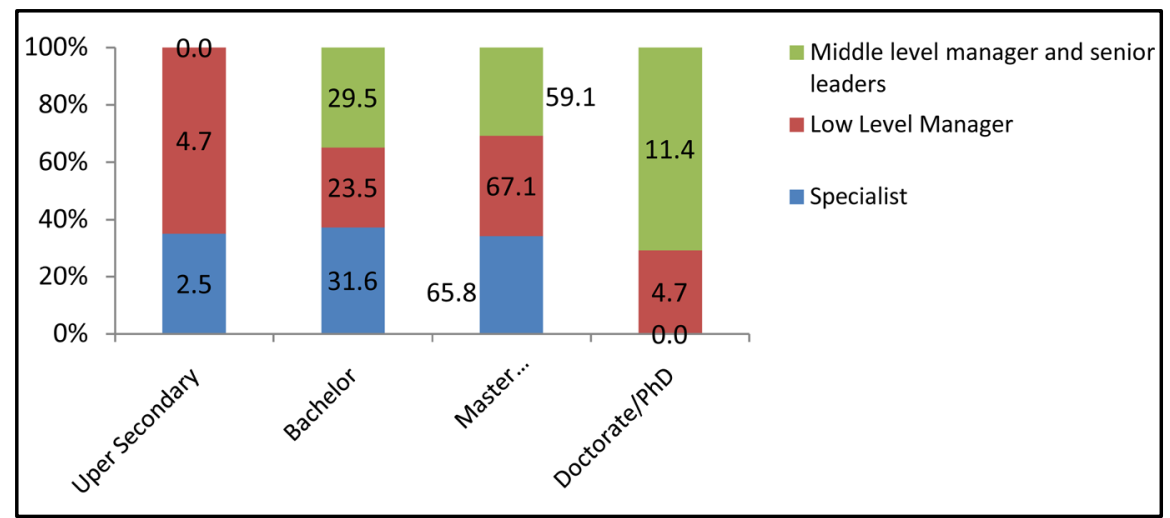

Figure 1. Educational qualification by position within organization of the respondents in percentage.

Table 2. Correlation matrix between employee engagement and demographic variables.

\begin{tabular}{|c|c|c|}
\hline & & Employee engagement \\
\hline \multirow[t]{3}{*}{ Gender } & Pearson correlation & 0.009 \\
\hline & Sig. (2-tailed) & 0.000 \\
\hline & $\mathrm{N}$ & 6456 \\
\hline \multirow[t]{3}{*}{ Highest level of education } & Pearson correlation & $0.080\left(^{* *}\right)$ \\
\hline & Sig. (2-tailed) & 0.000 \\
\hline & $\mathrm{N}$ & 6456 \\
\hline \multirow[t]{3}{*}{ Country of study } & Pearson correlation & $0.081\left(^{* *}\right)$ \\
\hline & Sig. (2-tailed) & 0.000 \\
\hline & $\mathrm{N}$ & 6456 \\
\hline \multirow[t]{3}{*}{ Age group } & Pearson correlation & $0.207\left(^{* *}\right)$ \\
\hline & Sig. (2-tailed) & 0.000 \\
\hline & $\mathrm{N}$ & 6456 \\
\hline \multirow[t]{3}{*}{ Years of experience } & Pearson correlation & $0.240\left(^{* *}\right)$ \\
\hline & Sig. (2-tailed) & 0.000 \\
\hline & $\mathrm{N}$ & 6456 \\
\hline \multirow[t]{3}{*}{ Years of experience within organization } & Pearson correlation & $0.129\left(^{* *}\right)$ \\
\hline & Sig. (2-tailed) & 0.000 \\
\hline & $\mathrm{N}$ & 6456 \\
\hline \multirow[t]{3}{*}{ Position within organization } & Pearson correlation & $0.035\left(^{* *}\right)$ \\
\hline & Sig. (2-tailed) & 0.005 \\
\hline & $\mathrm{N}$ & 6456 \\
\hline
\end{tabular}

${ }^{* *}$ Correlation is significant at the 0.01 level (2-tailed). ${ }^{*}$ Correlation is significant at the 0.05 level (2-tailed). 
characteristic and status in organization as below: no relationship with gender; it is significantly positive correlated $(p=0.000)$ with highest level of education of the employees; there is a positive significance relationship between the engagement and country of study because the $p=0.000$ ) this case, Pearson Correlation is 0.080 so the independent variable Country of study explains $8 \%$ of the variance in the dependent variable that in our case is employee engagement) and to conclude employee engagement has a significant relationship with age group.

As shown in Table 2, to find out the correlation between employee engagement and years of experience, a Pearson correlation was run, which indicates that years of experience has significant positive correlation with employee engagement among all employees in banks, which was statistically significant $(r=0.240, n=6456$, value of $p=0.000$, where $p<0.0005$ ).

There is a positive significance relationship between the engagement years of experience within organization because the $p=0.000$. Employee engagement has a significant relationship with position within organization too. Thus it is accepted the hypothesis from $\mathrm{H} 2$ to H7, and drown off so far the hypothesis H1. The analysis regarding hypothesis $\mathrm{H} 8$ will continue Section 4.4.

\subsection{One-Way ANOVA}

In order to test the influence of demographic characteristics on employee engagement, ANOVA was performed in SPSS. The one-way analysis of variance (ANOVA) is used to determine whether there are any significant differences between the means of two or more independent (unrelated) groups.

Table 3 shows that, among the demographic characteristics, only Gender ( $\mathrm{F}=17.494 ; p=0.06)$ has no significant influence on employee engagement, while others characteristics like Age group, Years of experience and Years of experience within organization, etc. have significant influence on employee engagement.

The results show that employees group age $50-59$, are the most engaged (mean $=4.38$ ) (Table 4). The result is significatively linked with the category of years of experience in the organisation, where the employees of the group "25 years and above" are the most engaged 87.6\% (mean = 4.38). Employees with an experience, group 5 - 10 years, they are $71 \%$ engaged with the organisation. While the analysis presented in Table 2, show that gender is not a significant determinat with employee engagement. While the category "Low level manager and senior leaders" presents the highest level of engagement, Mean $=3.7$ while does not differ significantly with the group of mangers at highest level.

\subsection{Simple Regression}

Aiming to analyse hypothesis H8, the authors will investigate weather in the model analysed and the data collected, if do exist a significant statistical relationship between communication and employee engagement. If a significant relationship will result, then the research will go in depth to establish a econometric model to measure the impact has the communication on employee engagement. Correlation will indicate and measure the relationship among two variables: Independet variables referring to Communication (organizational perspective, personal feedback, organizational integration, supervisory communication, communication climate, horizontal communication , media quality, subordinate communication) (Downs/Hazen 1977) [14] and Dependent variable referring to Employee Engagement (vigor, dedication, absorption) Schaufeli et al. (2002) [13].

As already known, the correlation values vary from -1 to 1 . The data produced Table 5, show that do exist a significative relation among the variables, and furthes do exist a positive correlation. Since the correlation is statistically significant and relation exist hypothesis H8 is proved. To continue in depth analyse of the relationship among variables a regresion analysis will measure the predict variable. The predicted varible of employee engagement is communication in organization. Simple regression allows determining the overall fit (variance explained) of the model and the relative contribution of the predictors to the total variance explained.

The theoretical model for the simple regression is:

$$
\text { Employee Engagement }=\beta_{0}+\beta_{1} x
$$

where $x$-communication organization.

SPSS Statistics generate quite a few tables of output for a simple regression analysis. In this section, we put only the three main tables required to understand the results from the multiple regression procedure. 
Table 3. One-way ANOVA between employee engagement and demographic variables.

\begin{tabular}{|c|c|c|c|c|c|c|}
\hline & & Sum of squares & df & Mean square & $\mathrm{F}$ & Sig. \\
\hline \multirow[t]{3}{*}{ Gender } & Between groups & 261.002 & 50 & 1.883 & 17.494 & 0.06 \\
\hline & Within groups & 648.149 & 6405 & 0.122 & & \\
\hline & Total & 909.151 & 6455 & & & \\
\hline \multirow[t]{3}{*}{ Highest level of education } & Between groups & 1283.284 & 196 & 6.547 & 52.632 & 0.000 \\
\hline & Within groups & 778.611 & 6259 & 0.124 & & \\
\hline & Total & 2061.895 & 6455 & & & \\
\hline \multirow[t]{3}{*}{ Country of study } & Between groups & 1695.432 & 196 & 8.650 & 29.501 & 0.000 \\
\hline & Within groups & 1835.258 & 6259 & 0.293 & & \\
\hline & Total & 3530.690 & 6455 & & & \\
\hline \multirow[t]{3}{*}{ Position within organization } & Between groups & 1696.417 & 196 & 8.655 & 42.207 & 0.000 \\
\hline & Within groups & 1283.512 & 6259 & 0.205 & & \\
\hline & Total & 2979.929 & 6455 & & & \\
\hline \multirow[t]{3}{*}{ Age group } & Between groups & 2335.984 & 196 & 11.918 & 52.679 & 0.000 \\
\hline & Within groups & 1416.056 & 6259 & 0.226 & & \\
\hline & Total & 3752.039 & 6455 & & & \\
\hline \multirow[t]{3}{*}{ Years of experience } & Between groups & 6345.674 & 196 & 32.376 & 50.418 & 0.000 \\
\hline & Within groups & 4019.223 & 6259 & 0.642 & & \\
\hline & Total & $10,364.897$ & 6455 & & & \\
\hline \multirow[t]{3}{*}{ Years of experience within organization } & Between groups & 1748.441 & 196 & 8.921 & 34.692 & 0.000 \\
\hline & Within groups & 1609.432 & 6259 & 0.257 & & \\
\hline & Total & 3357.873 & 6455 & & & \\
\hline
\end{tabular}

\subsubsection{The Model Fits}

Table 6 provides information about the $R, R^{2}$, adjusted $R^{2}$, and the standard error of the estimate, which can be used to determine how well a regression model fits the data that we have.

From the result of the table, $R$ can be considered to be one measure of the quality of the prediction of the dependent variable; in this case, Employee Engagement. A value of $R=0.675$, indicates a good level of prediction. $R^{2}$ value (also called the coefficient of determination), which is the proportion of variance in the dependent variable that can be explained by the independent variables. $R^{2}=0.630$ that the independent variables explain $63.0 \%$ of the variability of the depended variable.

\subsubsection{Statistical Significance}

The F-ratio in the ANOVA Table 7 is applied to test if the overall regression model is a good fit for the data. The table shows that the independent variables statistically predict significantly the depended variable, $F(1$, $6454)=3185.950, p<0.0005$. The regression model is a good fit of the data which indicates that the relationship is reliable and can be used to make predictions between employee communication and employee engagement level.

\subsubsection{Estimated Model Coefficients}

The general form of the equation to predict the theoretical model of employee engagement it is generated by Table 8. 
Table 4. Influence of demographic variables on employees engagement.

\begin{tabular}{|c|c|c|c|c|c|}
\hline \multicolumn{3}{|c|}{ Gender } & \multicolumn{3}{|l|}{ Age-group } \\
\hline & Mean & Std. deviation & & Mean & Std. deviation \\
\hline Male & 3.59 & 0.69 & $20-29$ years & 3.59 & 0.61 \\
\hline Female & 3.71 & 0.62 & $30-39$ years & 3.65 & 0.65 \\
\hline Total & 3.67 & 0.64 & $40-49$ years & 3.83 & 0.56 \\
\hline \multicolumn{3}{|c|}{ Highest completed level of education } & 50 - 59 years & 4.38 & 0.61 \\
\hline & Mean & Std. deviation & Total & 3.67 & 0.64 \\
\hline Upper secondary & 3.68 & 0.86 & \multicolumn{3}{|c|}{ Years of experience } \\
\hline Bachelor & 3.74 & 0.71 & & Mean & Std. deviation \\
\hline Master professional/scientific & 3.65 & 0.60 & Below 5 years & 3.6 & 0.6 \\
\hline Doctorate/PhD & 3.32 & 0.44 & 5 - 10 years & 3.7 & 0.7 \\
\hline Total & 3.67 & 0.64 & $10-15$ years & 3.9 & 0.5 \\
\hline \multicolumn{3}{|c|}{ Place of study } & $15-20$ years & 3.9 & 0.2 \\
\hline & Mean & Std. deviation & $20-25$ years & 3.8 & 1.1 \\
\hline State university in Albania & 3.64 & 0.65 & 25 years and above & 4.1 & . \\
\hline Private university in Albania & 3.69 & 0.68 & Total & 3.7 & 0.6 \\
\hline University in another state & 3.79 & 0.60 & \multicolumn{3}{|c|}{ Position within organization } \\
\hline Total & 3.67 & 0.64 & & Mean & Std. deviation \\
\hline \multicolumn{3}{|c|}{ Years of experience in the organization } & Specialist & 3.65 & 0.63 \\
\hline & Mean & Std. deviation & Low Level Manager & 3.7 & 0.68 \\
\hline Below 5 years & 3.64 & 0.59 & Middle level manager and senior leaders & 3.69 & 0.68 \\
\hline 5 - 10 years & 3.55 & 0.70 & Total & 3.67 & 0.64 \\
\hline $10-15$ years & 3.73 & 0.51 & & & \\
\hline 15 - 20 years & 3.88 & 0.48 & & & \\
\hline $20-25$ years & 4.00 & 0.48 & & & \\
\hline 25 years and above & 4.38 & 0.59 & & & \\
\hline Total & 3.67 & 0.64 & & & \\
\hline
\end{tabular}

Regression analysis also revealed that the employee engagement can be predicted correctly by employee communication since the $r^{2}$ coefficient of the determination is 0.630 .

The regression model for employee engagement:

$$
\text { Employee Engagement }=1.464+0.622 \times R=63 \%
$$

The data analysis show that when the independent variable differs increases by one unit in Likert scale (not at all satisfied) into (not satisfied), the level of employee engagement in the organisation is increased by $12.44 \%$. Indeed, when the independent variable increases by four units in Likert scale (not at all satisfied) into (highly satisfied), the level of employee engagement in the organisation is increased by $49.76 \%$.

\section{Conclusion}

The theoretical contribution of this paper lies in establishing and testing a model of the relationship between 
Table 5. Correlation between employee engagement and organizational communication.

\begin{tabular}{cccc}
\hline & \multicolumn{3}{c}{ Correlations } \\
\hline & Employee engagement & Organizational communication \\
\hline & Pearson correlation & 1 & $0.575^{* *}$ \\
Employee & Sig. (2-tailed) & & 0.000 \\
engagement & $\mathrm{N}$ & 6456 & 6456 \\
\hline
\end{tabular}

${ }^{* * *}$ Correlation is significant at the 0.01 level (2-tailed).

Table 6. Model summary for the simple regresion.

\begin{tabular}{ccccc}
\hline & \multicolumn{3}{c}{ Model summary } \\
\hline Model & $\mathrm{R}$ & $\mathrm{r}$ square & Adjusted R square & Std. error of the estimate \\
\hline 1 & $0.675^{\mathrm{a}}$ & 0.630 & 0.630 & 0.52 \\
\hline
\end{tabular}

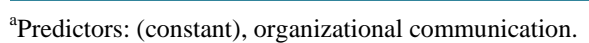

Table 7. ANOVA for the model.

\begin{tabular}{|c|c|c|c|c|c|c|}
\hline \multicolumn{7}{|c|}{ ANOVA $^{s}$} \\
\hline & Model & Sum of squares & df & Mean square & $\mathrm{F}$ & Sig. \\
\hline \multirow{3}{*}{1} & Regression & 890.412 & 1 & 890.412 & 3185.950 & $0.000^{\mathrm{a}}$ \\
\hline & Residual & 1803.770 & 6454 & 0.279 & & \\
\hline & Total & 2694.183 & 6455 & & & \\
\hline
\end{tabular}

${ }^{\mathrm{a} P r e d i c t o r s: ~(c o n s t a n t), ~ o r g a n i z a t i o n a l ~ c o m m u n i c a t i o n . ~}{ }^{\mathrm{b}}$ Dependent variable: employee engagement.

Table 8. Coefficients for the model.

\begin{tabular}{|c|c|c|c|c|c|c|}
\hline \multicolumn{7}{|c|}{ Coefficients $^{\mathrm{a}}$} \\
\hline & \multirow{2}{*}{ Model } & \multicolumn{2}{|c|}{ Unstandardized coefficients } & \multirow{2}{*}{$\begin{array}{c}\text { Standardized coefficients } \\
\text { Beta }\end{array}$} & \multirow{2}{*}{$\mathrm{t}$} & \multirow{2}{*}{ Sig. } \\
\hline & & B & Std. error & & & \\
\hline \multirow[b]{2}{*}{1} & (Constant) & 1.464 & 0.040 & & 36.794 & 0.000 \\
\hline & $\begin{array}{l}\text { Organizational } \\
\text { communication }\end{array}$ & 0.622 & 0.011 & 0.575 & 56.444 & 0.000 \\
\hline
\end{tabular}

${ }^{\mathrm{a}}$ Dependent variable: employee engagement.

employee engagement and organizational communication, and investigating the demographic determinants of employee engagement. Analysed and tested in bank sector in Albania, we proved that demographic dimensions were related with employee engagement. The data analysis proved that employee engagement had a positive relation with the years of experience; employees with more years of experience were more engaged. In addition, the research proved that group age had a positive correlation with employee engagement (the highest level of engagement mean $=4.38$ resulted group age 50 - 59 years).

The analysis shows that the position in the organisation has a relationship with employee engagement and the data show that the low levels of managers are more engaged than the group of middle and highest level of managers. The level of education significantly has a relation with employee engagement, while it is proved that gender has no significance on employee engagement, and man or woman can be engaged almost equally.

Communication practices in the organisation, significantly impact the employee engagement data show. The good practices and establishing a healthy communication climate will enhance employee engagement.

The model is tested in developing countries still facing political and economic challenges. May be some results can be different in countries with high level of stability and good practices of organisations established. 


\section{Direction for Future Research}

Employee engagement research studies are interesting to be analysed under the view of other factors that might influence, as for the role of the leadership, different styles which is more correlated and linked.

One of the limitations of the study may be that the communication practices in the organisations are relatively new, considering that the private sector in Albania was liberalised after the year 1991. Newly presented practices of communication need still to be improved until considered well structures and strong basis. The horizontal communication, informal one, need further to be analysed.

\section{References}

[1] Harter, J.K., Schmidt, F.L. and Keyes, C.L. (2002) Business-Unit Level Relationship between Employee Satisfaction, Employee Engagement and Business Outcomes: A Meta Data Analysis. Journal of Applied Psychology, 87, 268-279. http://dx.doi.org/10.1037/0021-9010.87.2.268

[2] The Gallup Organisation (2006) www.gallup.com

[3] Ott, B. (2007) Investors, Take Note: Engagement Boosts Earnings. The Gallup Management Journal. http://web.ebscohost.com/ehost/pdf?vid=4\&hid=21\&sid=8470b965-28f0-4f5a-9522-6c297e68b789\%40sessionmgr8

[4] Towers Perrin-ISR (2006) Engaged Employees Help Boost the Bottom line. Towers Perrin-ISR, US.

[5] Frank, F.D., Finnegan, R.F. and Taylor, C.F. (2004) The Race for Talent: Retaining and Engaging Workers in the 21st Century. Human Resource Planning, 27, 12-25.

[6] Dalal, R.S., Brummel, B.J., Wee, S. and Thomas, L.L. (2008) Defining Employee Engagement for Productive Research and Practice. Industrial and Organizational Psychology, 1, 52-55. http://dx.doi.org/10.1111/j.1754-9434.2007.00008.x

[7] Marcey, W.H. and Schneider, B. (2008) The Meaning of Employee Engagement. Industrial and Organizational Pshycology, 1, 3-30. http://dx.doi.org/10.1111/j.1754-9434.2007.0002.x

[8] Goffman, E. (1959) The Presentation of Self in Everyday Life. Doubleday Anchor, New York, 5-15.

[9] Goffman, E. (1961) Encounters: Two Studies in the Sociology of Interaction. Bobbs-Merrill, Indianapolis.

[10] Kahn, W.A. (1960) Psychological Conditions of Personal Engagement and Disengagement at Work. Academy of Management Journal, 33, 692-724. http://dx.doi.org/10.2307/256287

[11] Maslach, C., Jackson, S.E. and Leiter, M.P. (1996) Maslach Burnout Inventory. Paolo Alto Consulting Psychologist Press, Paolo Alto.

[12] Harter, J.K. and Schmidt, F.L. (2006) Connecting Employee Satisfaction to Business Unit Performance. In: Kraut, A.I., Ed., Getting Action from Organizational Surveys: New Concepts, Technologies, and Applications, Jossey-Bass, San Francisco, 33-52.

[13] Schaufeli, W.B., Salanova, M. and Gonza, R.V. (2002) The Measurement of Engagement and Burnout: A Two Sample Confirmatory Factor Analytic Approach. Journal of Happiness Studies, 3, 71-92. http://dx.doi.org/10.1023/A:1015630930326

[14] Downs, C.W. and Hazen, M.D. (1977) A Factor Analytic Study of Communication Satisfaction. The Journal of Business Communication, 3, 63-73. http://dx.doi.org/10.1177/002194367701400306

[15] Frank, A. and Brownell, J. (1989) Organizational Communication and Behaviour: Communicating to Improve Performance. Holt, Rinehart \& Winston, Orlando.

[16] Durkin, D. (2007) How Loyalty and Employee Engagement Add up to Corporate Profits. Chief Learning Officer, 6, 30-34.

[17] Prime Resources, Inc. (2009) Tips for Good Employee Communication. http://primeresources.com/Articles/Employee\%20Relations/tips-for-good-employee-communication.pdf

[18] Steyen, B. and Groenewald, R. (1996) Make Productivity Happen and Get the Competitive Edge through Excellence in Corporate Communication. Proceedings of the Conference of the World Productivity Assembly on Achieving WorldClass Competitiveness, Johanesburg, 3 September 1996.

[19] Lohr, L.S. (2010) Sampling: Design and Analysis. 2nd Edition, Arizona State University, Tempe, 567-572. 